\title{
Erişkin Hastada Rektum Karsinomu Nedeniyle Gelişen Sigmoido-Rektal İnvajinasyonun ÇKBT Bulguları
}

\author{
Multislice CT Findings of Sigmoido-rectal Invagination Due to Rectal Carcinoma in an \\ Adult Patient. A Case Report \\ Mustafa KARA ${ }^{1}$ \\ ${ }^{1}$ Sakarya Yenikent Devlet Hastanesi, Radyoloji Kliniği, Sakarya
}

ABSTRACT

\begin{abstract}
öz
İnvajinasyon erişkinlerde nadirdir. İnvajinasyon olgularının yaklaşık \%5'i erişkinlerde görülür. Erişkinlerde izlenen invajinasyon olgularında \%70-90 oranında neden bilinmektedir. Bunların da yaklaşık \%40'nın sebebi malign tümörlerdir.

60 yaşında karın ağrısından şikâyeti olan ve rekto-sigmoid büyük boyutlu karsinomu izlenen ve buna sekonder sigmoido-rektal invajinasyon gelişen olgumuzun çok kesitli bilgisayarlı tomografi (ÇKBT) bulgularını sunuyoruz.
\end{abstract}

Anahtar Kelimeler: Rektum karsinomu, invajinasyon, bilgisayarlı tomografi
Intussusception is a condition affetcting primarily children, but in adults are relatively rare. About $5 \%$ of cases occur in adult, but $70 \%-90 \%$ of cases there are demonstrable cause and about $40 \%$ of there are caused by malignant neoplasm. We report the case of a 60 year old man suffering from abdominal pain.

This case report computed tomography images for the diagnosis of adult intussusception.

Keywords: Rectum cancer, invagination, computed tomography 


\section{GíRiş}

Erişkinlerde invajinasyon çocuklara göre daha nadir görülmektedir. Ancak erişkinde izlenen invajinasyonların \%70-90 nedeni bilinmektedir ve yaklaşık \%40'nın sebebi malign tümörledir $(1,2)$.

Bilgisayarlı tomografi (BT) nonspesifik abdominal ağrıların ve abdominal kitlelerin değerlendirilmesinde yaygın bir şekilde uygulanmaktadır. Bu durumlarda ilk BT bulgusu olarak invajinasyon karşımıza çıkabilir (2). İnvajinasyonun gerçek nedenini saptamada BT her zaman yeterli değildir. Çünkü neden olan kitle birçok vakada küçük ve sıklıkla invajinasyon içinde saklıdır (3). Kolonik invajinasyon genellikle adenokarsinom ve lenfoma gibi malign tümörler sebebiyle oluşmaktadır. Ancak \%30 kadar leiyomyom, endometriozis ve anostomoz uçları gibi benign nedenlerle de meydana gelebilir.

Erken dönem invajinasyon bulgusu olarak BT' de hedef görünümü saptanabilir. Ultrasonografi (US), manyetik rezonans görüntüleme (MR) ve ÇKBT invajinasyonun teşhisinde yüksek güvenirlik oranına sahiptir. ÇKBT'nin invajinasyon tanısında duyarlılık ve özgüllüğü oldukça yüksektir (4). BT'deki hedef görünümü invajinasyon için tanısal olabilir. ÇKBT'de ince kesit kalınlıkları kullanılarak yapılan incelemelerde farklı planlarda yapılan rekonstrüksiyonlarla (MPR) invajinasyonun tanısı daha kolay konulup, yapısı daha ayrıntılı değerlendirilebilir (5).

\section{OLGU SUNUMU}

60 yaşında karın ağrısı olan hastaya, karın ağrısı nedenlerinin ekartasyonu için ÇKBT tetkiki yapıldı. İncelemede, $128 \times 0,6 \mathrm{~mm}$ dedektör kolimasyonu, $1 \mathrm{~mm}$ kesit kalınlığı ve 0,9 Pitch değeri kullanıldı. $100 \mathrm{ml}$ non-ionik intravenöz kontrast madde ve $1500 \mathrm{ml}$ su içerisinde $125 \mathrm{ml}$ laktuloz çözeltisi negatif oral kontrast madde olarak kullanıldı. Tetkik portal fazda (kontrast verilmeye başlanmasından 60 sn sonra) yapıldı. Sigmoido-rektal invajinasyon ile uyumlu olarak aksiyel görüntülerde hedef görünümü olan hastanın, koronal ve sagittal MPR görüntülerinde, sigmoid kolonun rektum içerisine invajine olduğu ve rekto-sigmoid bileşkede tümöral kitlesi olduğu izlendi (Şekil I). Ameliyat sonrası yapılan his- topatolojik incelemede rezeke intusespsiyon spesmeninde adenokanser tespit edilmiştir.

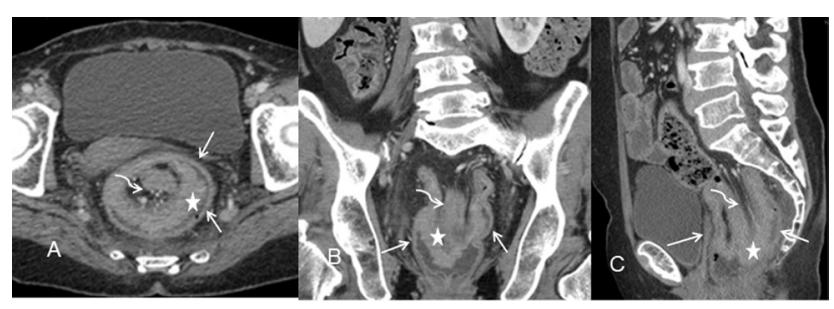

Şekil I: Aksiyel (A), koronal (B) ve sagital (C) plan ÇKBT görüntülerde; rektum (düz oklar) içerisine, sigmoid kolonun ve komşu yağ planlarının (eğri okla) invajine olduğu izlenmekte. İnvajine olan sigmoid kolonda kalın tümöral doku (yıldızlar) gözükmektedir. Aksiyel görüntüde tipik hedef görünümü izlenmektedir (A).

\section{TARTIŞMA}

İnvajinasyon çocuklarda sık görülmekle birlikte nedeni genelde ortaya konamamaktadır. Erişkinlerde invajinasyon daha nadirdir. Ancak erişkinlerde invajinasyon sebebi genellikle saptanabilmektedir. İncebağırsak polipleri malign kitleleri, kolonik benign ve malign kitleler erişkinlerde invajinasyon sebebi olabilmektedir. Sigmoido-rektal invajinasyon oldukça nadir olup genellikle malign lezyonlara eşlik etmektedir. ÇKBT erişkinlerde invajinasyonu ve nedenini ortaya koymakta çok yüksek duyarlılığa sahiptir. Bu nedenle karın ağrısı, kabızlık, ishal vb. dispeptik şikâyetlerle gelen erişkin hastalarda invajinasyonda ayrıcı tanıda düşünülmelidir. ÇKBT hem invajinasyon tanısında hem de altta yatan nedeni saptamada tercih edilecek tanı yöntemidir.

\section{KAYNAKLAR}

1. Kithara H, Horiuchi A, Nakayama $Y$, et al. Retrograde intussusception caused by a sigmoid colonic tumor: reduction by the use of a transanal drainage tube. Gastrointest Endosc 2005;61(3):482-4.

2. Takeuchi K,TsuzukiY, AndoT, et al.The diagnosis and treatment of adult intususception. Clin Gastroenterol 2003;36(1):18-21.

3. Byrne AT, Goeghegon T, Govender $P$, et al. The imaging of intussusception. J Clin Radial 2005;60(1):39-46.

4. Floemer F, Bissig $H$, Oertli $D$, et al. Multislice BT in adult colocolic intussusception. Emerg Radial 2008;15(5):361-6.

5. Moon $\mathrm{JH}$, Park $\mathrm{CH}$, Kim $\mathrm{KO}$, et al. Sigmoidorectal intussusception caused by a malignant tumor of the sigmoid colon: computed tomography with three dimensional reconstruction. Endoscopy 2006;38 (suppl 2):E67. 